\title{
UPAYA PENINGKATAN KETERAMPILAN PROSES SAINS DAN HASIL BELAJAR SISWA BERBASIS SUMBER BELAJAR LINGKUNGAN UNTUK SISWA KELAS XI.MIPA.1 SMAN 3 MUARO JAMBI TAHUN PELAJARAN 2017-2018
}

\author{
RINA EVA SEMBIRING \\ SMA Negeri 3 Muaro Jambi Provinsi Jambi \\ rinaeva4@gmail.com
}

\begin{abstract}
ABSTRAK
Penelitian ini bertujuan untuk meningkatkan keterampilan saintifik siswa kelas XI.MIPA.1 SMA Negeri 3 Muaro Jambi. Subjek dalam penelitian ini adalah siswa kelas XI.MIPA.1 SMA Negeri 3 Muaro Jambi tahun ajaran 2017/2018 pada materi pelajaran dunia tumbuhan (Plantae). Penelitian dilaksanakan dalam dua siklus. Setiap siklus dilaksanakan sebanyak 3 kali pertemuan. Hasil dari penelitian ini adalah terjadinya peningkatan dari siklus I ke siklus II. Keterampilan saintifik siswa mengalami peningkatan dari prasiklus, siklus I sampai siklus II. Pada prasisklus meningkat $60,6 \%$ menjadi $65,3 \%$ pada siklus I, dan dari siklus I $65,3 \%$ meningkat menjadi $77,2 \%$ pada siklus II. Berdasarkan data hasil penelitian pembelajaran dengan berbasis sumber belajar pada lingkungan untuk meningkatkan keterampilan saintifik pada siswa, oleh karena itu peneliti menyarankan kepada guru untuk menerapkan model ini dalam pembelajaran Biologi.
\end{abstract}

Kata Kunci:keterampilan saintifik, sumber belajar lingkungan, biologi

\section{PENDAHULUAN}

Pendidikan pada hakikatnya adalah usaha sadar untuk mengembangkan kepribadian, di dalam atau di luar sekolah dan berlangsung seumur hidup. Oleh karena itu, pendidikan merupakan suatu kewajiban setiap manusia, terutama bagi bangsa Indonesia sebagai bangsa yang bermoral dan bermartabat untuk dapat mengukuhkan eksistensinya dalam menghadapi era globalisasi. Proses belajar yang unggul adalah proses belajar yang melibatkan peran guru yang profesional dan mumpuni di bidangnya(Tussaadiyah, 2017).

Belajar merupakan suatu proses yang dilakukan oleh individu yang memungkinkan timbulnya perubahan dalam dirinya baik berupa pengetahuan keterampilan dan sikap dengan syarat perolehan perubahan tersebut bukan disebabkan karena adanya kematangan (maturity), perubahan insting atau dengan nafsu. Perubahan yang dimaksud adalah perubahan ke arah yang lebih baik dan bersifat relatif permanen yaitu dalam waktu yang lama pula.

Proses pendidikan berlangsung melalui kegiatan belajar. Belajar sendiri atau dengan bantuan guru, belajar dari buku atau media elektronika, belajar di sekolah, di rumah atau lingkungan keluarga, di lingkungan kerja atau di lingkungan masyarakat akan memberikan perubahan-perubahan pada diri orang yang belajar (Khojin, dkk, 2017). Keberhasilan dalam pendidikan tidak lepas dari kegiatan proses belajar mengajar. Belajar merupakan tindakan dan perilaku siswa yang kompleks. Sebagai tindakan, maka belajar hanya dialami oleh siswa sendiri. Proses belajar terjadi karena siswa memperoleh sesuatu yang ada di lingkungan sekitar. Dalam ilmu pendidikan, terutama pendidikan biologi banyak sekali berhubungan dengan ilmuilmu dan konsep-konsep nyata yang banyak ditemui di lingkungan sekitar, sehingga dalam belajar biologi perlu terjun ke lingkungan untuk mengamati secara langsung fenomenafenomena dan permasalahan lingkungan yang terjadi. Melalui lingkungan sebagai sumber belajar diharapkan dapat memberikan suasana berbeda dan menyenangkan serta memberikan pengalaman baru bagi siswa. Melalui lingkungan, diharapkan siswa dapat belajar dari apa yang dia lihat, apa yang dirasakan serta apa yang ditemukannya di lingkungan, sehingga pembelajaran akan lebih bermakna. Pemahaman terhadap suatu konsep melalui pembelajaran di lingkungan akan memiliki sifat dapat bertahan lebih lama. 


\section{SCIENCE : Jurnal Inovasi Pendidikan Matematika dan IPA Vol. 1 No. 2 Agustus 2021 e-ISSN : 2797-1031 | p-ISSN : 2797-0744}

Hal ini menuntut sekolah untuk mengembangkan suatu cara pembelajaran yang mengoptimalkan keterlibatan siswa dalam menanggapi peristiwa yang terjadi di dalam lingkungan. Lingkungan yang dipelajari oleh siswa berupa keadaan alam, benda-benda, hewan, tumbuh-tumbuhan, manusia, atau hal-hal yang dijadikan bahan belajar. Tindakan belajar tentang suatu hal tersebut tampak sebagai perilaku belajar yang tampak dari luar, sedangkan mengajar menunjukkan apa yang harus dikerjakan atau dilakukan oleh seorang guru sebagai pengajar. Dalam proses pembelajaran diharapkan antara guru, siswa, dan lingkungan belajar saling mendukung sehingga akan tercapai tujuan pembelajaran (Wahid, dkk, 2017). Model pembelajaran berbasis lingkungan merupakan model pembelajaran yang menggunaan fasilitas belajar dari lingkungan alam sekitar sebagai sumber belajar, hal tersebut sangat dianjurkan untuk digunakan dengan tujuan mengembangkan keterampilan saintifik siswa. Sehingga penggunaan fasilitas belajar berpengaruh terhadap keterampilan saintifik dan hasil belajar siswa (Asih, 2017).

Menurut (Hasbullah, 2012: 33) bahwa lingkungan sekolah merupakan "Lingkungan pendidikan utama yang kedua". Siswa-siswi, guru, administrator, konselor hidup bersama dan melaksanakan pendidkan secara teratur dan terencana dengan baik, sedangkan lingkungan keluarga merupakan lembaga pendidikan tertua, bersifat informal, yang pertama dan utama dialami oleh anak serta lembaga pendidikan yang bersifat kodrati dimana orangtua bertanggung jawab memelihara, merawat, melindungi dan mendidik anak agar tumbuh dan berkembang dengan baik (Muslich, 2016).Rahmatiah (2015) menyatakan bahwa Biologi merupakan bagian dari sains yang terdiri dari produk dan proses. Biologi sebagai produk terdiri dari fakta, konsep, teori, dan hukum yang berkaitan dengan makhluk hidup. Sedangkan biologi sebagai proses terdiri dari keterampilan proses yang dapat dilakukan dengan metode ilmiah. Salah satu pendekatan pembelajaran yang menggunakan metode ilmiah dalam pembelajaran yaitu pendekatan sainstifik. Pendekatan saintifik merupakan pendekatan yang menggunakan langkah-langkah serta kaidah ilmiah dalam proses pembelajaran. Terutama pada bidang pengetahuan alam khususnya mata pelajaran Biologi (Wahyuni, 2017). Dengan demikian, diharapkan dengan adanya sumber belajar berbasis lingkungan yang unggul dan memadai akan mampu membantu siswa dalam mengembangkan keterampilan saintifiknya dalam memahami kejadian ilmiah di sekitarnya.

Dalam biologi dipelajari permasalahan yang berkait dengan fenomena alam dan berbagai permasalahan dalam kehidupan masyarakat. Fenomena alam dalam biologi dapat ditinjau dari objek, persoalan, tema, dan tempat kejadiannya. Pembelajaran biologi memerlukan kegiatan penyelidikan, baik melalui observasi maupun eksperimen, sebagai bagian dari kerja ilmiah yang melibatkan keterampilan proses yang dilandasi sikap ilmiah. Selain itu, pembelajaran biologi mengembangkan rasa ingin tahu melalui penemuan berdasarkan pengalaman langsung yang dilakukan melalui kerja ilmiah atau bersifat saintifik (Midin, 2013). Pembelajaran saintifik merupakan pembelajaran yang mengadopsi langkah-langkah saintis dalam membangun pengetahuan melalui metode ilmiah. Dalam proses pembelajaran menyentuh tiga ranah yaitu sikap, pengetahuan dan keterampilan (Sariningsih, 2016). Hal ini sesuai dengan paradigma dalam pembelajaran pengetahuan alam khususnya Biologi. Selaras dengan penjelasan Daryanto (2014:51) yang mengungkapkan bahwa pembelajaran dengan pendekatan saintifik merupakan proses pembelajaran yang didesain sedemikian rupa agar siswa secara aktif mengkonstruksi konsep, hukum atau prinsip melalui tahapan-tahapan mengamati, merumuskan masalah, mengajukan atau merumuskan hipotesis, mengumpulkan data dengan berbagai teknik, menganalisis data, menarik kesimpulan dan mengkomunikasikan konsep, hukum atau prinsip yang ditemukan.

Hasil observasi pada SMA Negeri 3 Muaro Jambi, sekolah tersebut memiliki lingkungan yang cukup luas dan terlihat proses pembelajaran sudah berjalan dengan baik. Guru sudah pernah merancang pembelajaran untuk membangun keterampilan proses sains. pada siswa namun hanya pada aspek keterampilan seperti mengamati, dan mengkomunikasikan. Oleh karena itu untuk keterampilan proses yang lain perlu dikembangkan seperti 


\section{SCIENCE : Jurnal Inovasi Pendidikan Matematika dan IPA Vol. 1 No. 2 Agustus 2021 e-ISSN : 2797-1031 | p-ISSN : 2797-0744}

keterampilan sosial, dan kemampuan mengklasifikasikan objek. Selain keterampilan proses sains pada siswa yang masih rendah, hasil belajar siswa juga masih rendah, dari 31 siswa dengan KKM 70 hanya 38,7\% dengan jumlah 12 siswa yang tuntas sedangkan siswa yang memperoleh nilai dengan kategori belum tuntas mencapai $61,3 \%$ atau 19 siswa. Di lingkungan tersebut juga terdapat halaman depan sekolah dan kebun singkong dibagian belakang. Akan tetapi, lingkungan tersebut belum dimanfaatkan secara maksimal oleh guru dan siswa dalam pembelajaran biologi untuk mempelajari ekosistem. Padahal lingkungan merupakan sumber belajar yang besar manfaatnya. Hal tersebut mengakibatkan keterampilan saintifik siswa tidak tergali dengan baik dan penguasaan konsep oleh siswa kurang maksimal, dikarenakan proses pembelajaran biologi kelas XI.MIPA.1 SMA Negeri 3 Muaro Jambi masih menggunakan metode ceramah dan terkadang menggunakan metode diskusi.

Melihat permasalahan tersebut, untuk mengembangkan keterampilan saintifik dan hasil belajar siswa, peneliti menggunakan suatu model pembelajaran berbasis sumber belajar lingkungan. Model pembelajaran berbasis lingkungan merupakan pembelajaran yang memanfaatkan lingkungan sebagai sarana dan sumber belajar, sehingga dapat memberikan pengalaman bermakna kepada siswa melalui pengalaman langsung yaitu pengamatan tumbuhtumbuhan di lingkungan sekitar sekolah.

Menurut Mudjiono, dkk (2006: 21) bahwa "ada berbagai keterampilan dalam keterampilan proses, terdiri dari keterampilan-keterampilan dasar (basic skills) dan ketrampilan-keterampilan terintegrasi (integrated skills). Keterampilan-keterampilan dasar terdiri darienam keterampilan, yakni: mengobservasi, mengklasifikasi, memprediksi, mengukur, menyimpulkan, dan mengkomunikasikan". Menurut Rezba dan Wetzel Cit dalam Pertiwi, dkk (2020), menyatakan bahwa: Keterampilan proses sains terpadu meliputi: melakukan pengamatan (Observasi), menafsirkan pengamatan (Interpretasi), mengelompokkan (Klasifikasi), meramalkan (Prediksi), berkomunikasi, berhipotesis, merencanakan percobaan atau penyelidikan, menerapkan konsep atau prinsip, mengajukan pertanyaan.

Berdasarkan latar belakang tersebut, peneliti memilih suatu model pembelajaran yang diharapkan dapat meningkatkan keterampilan proses sains yaitu menggunakan fasilitas belajar di lingkungan alam sekitar. Karena model pembelajaran ini diharapkan akan menciptakan suasana pembelajaran yang lebih kontekstual, merangsang berbagai kemampuan siswa dalam proses pembelajaran dan menciptakan proses belajar yang lebih bermakna sebab siswa dihadapkan pada kondisi yang sebenarnya. Hal tersebut senada dengan pendapat Hamzah (2011) bahwa "konsep pembelajaran dengan menggunakan lingkungan memberikan peluang yang sangat besar kepada siswa untuk meningkatkan hasil belajarnya, dan secara umum konsep pembelajaran dengan menggunakan lingkungan dapat meningkatkan motivasi belajar dari siswa".

\section{METODE PENELITIAN}

Penelitian ini merupakan Penelitian Tindakan Kelas (PTK) yang dilaksanakan pada semester genap tahun pelajaran 2017/2018 pada siswa kelas XI.MIPA.1 SMA Negeri 3 Muaro Jambi. pada standar kompetensi memahami manfaat keanekaragaman hayati, dengan kompetensi dasar mendeskripsikan ciri-ciri divisio dalam dunia tumbuhan dan peranannya bagi kelangsungan hidup di bumi. Penelitian tindakan kelas ini dilaksanakan dalam 2 siklus yang meliputi tahap-tahap dalam penelitian yaitu: 1) perencanaan, 2) pelaksanaan tindakan, 3) observasi dan evaluasi tindakan, dan 4) refleksi dari perjalanan setiap pertemuan yang dilaksanakan selama pembelajaran. Masing-masing siklus terdiri dari 3 kali pertemuan dengan alokasi waktu ( $2 \times 45$ menit) sedangkan penelitian dilaksanakan mulai tanggal 1 Februari sampai dengan 7 Maret 2018.

Penelitian dilaksanakan di SMA Negeri 3 Muaro Jambi pada semester genap tahun pelajaran 2017/2018 dengan subjek penelitian siswa kelas XI.MIPA.1 dengan jumlah siswa 31 siswa dengan tingkat kemampuan yang beragam. Sedangkan objek penelitian yaitu 
keterampilan proses sains dan hasil belajar kognitif dengan menggunakan model pembelajaran berbasis lingkungan.

Sebelum penelitian, peneliti melaksanakan survey lapangan yaitu lingkungan sekitar sekolah yang terdapat tumbuh-tumbuhan. Hal ini dilakukan untuk mempermudah dalam proses pembelajaran. Selanjutnya peneliti melaksanakan penelitian dengan mengkaji materi yang akan dilakukan selama pembelajaran dan mempersiapkan segala perangkat pembelajaran yang akan digunakan selama penelitian seperti silabus, rencana pelaksanaan pembelajaran serta Lembar Kerja Siswa (LKS) sebagai evaluasi penilaian keterampilan proses sains.

Tindakan penelitian dikatakan berhasil apabila persentase setiap keterampilan telah mencapai target. Adapun target keterampilan proses yangakan dicapai dalam penelitian ini adalah:

Tabel 1. Indikator Aspek Keterampilan Proses Sains yang diamati

\begin{tabular}{|c|c|c|c|}
\hline No & $\begin{array}{l}\text { Keterampilan proses } \\
\text { sains }\end{array}$ & Indikator & $\begin{array}{l}\text { Rata-rata } \\
\text { target yang } \\
\text { Ingin dicapai } \\
\end{array}$ \\
\hline 1 & $\begin{array}{l}\text { Keterampil } \\
\text { an } \\
\text { mengobser } \\
\text { vasi }\end{array}$ & $\begin{array}{ll}\text { a. } & \text { Mengamati objek } \\
\text { pengamatan/tumbuhan } \\
\text { b. Mengumpulkan/menggunakan fakta yang } \\
\text { relevan dan memadai sesuai dengan hasil } \\
\text { pengamatan }\end{array}$ & $\begin{array}{l}\geq 80 \% \\
\geq 80 \%\end{array}$ \\
\hline 2 & $\begin{array}{l}\text { Keterampilan } \\
\text { mengklasifikasi } \\
\text { objek }\end{array}$ & $\begin{array}{l}\text { a. Mencari ciri-ciri khusus pada masing- } \\
\text { masing tumbuhan } \\
\text { b. Mencari persamaan dan perbedaan objek } \\
\text { pengamatan/tumbuhan berdasarkan ciri- } \\
\text { cirinya } \\
\text { c. Membandingkan objek } \\
\text { pengamatan/tumbuhan berdasarkan ciri- } \\
\text { cirinya }\end{array}$ & $\begin{array}{l}\geq 75 \% \\
\geq 75 \%\end{array}$ \\
\hline 3 & $\begin{array}{l}\text { Keterampilan } \\
\text { sosial/kerjasama } \\
\text { kelompok }\end{array}$ & $\begin{array}{l}\text { a. Ikut mengamati pada masing-masing } \\
\text { objek pengamatan/tumbuhan } \\
\text { b. Ikut mencari objek } \\
\text { pengamatan/tumbuhan di } \\
\text { lingkungan } \\
\text { c. Mengajukan pendapat dalam } \\
\text { kelompoknya } \\
\text { d. Menanggapi pendapat dari } \\
\text { kelompoknya }\end{array}$ & $\begin{array}{l}\geq 75 \% \\
\geq 75 \%\end{array}$ \\
\hline 4 & $\begin{array}{l}\text { Keterampilan } \\
\text { mengkomunikasikan } \\
\text { /menyampaikan } \\
\text { perolehan }\end{array}$ & $\begin{array}{l}\text { a. Menjelaskan hasil pengamatan secara } \\
\text { lisan } \\
\text { b. Menyampaikanperolehanmelaluitabel } \\
\text { c. Mengajukan pertanyaan dengan } \\
\text { kelompok yang presentasi } \\
\text { d. Menjawab pertanyaan dari anggota } \\
\text { kelompok lain }\end{array}$ & $\begin{array}{l}\geq 75 \% \\
\geq 75 \% \\
\geq 75 \% \\
\geq 75 \%\end{array}$ \\
\hline
\end{tabular}

\section{HASIL DAN PEMBAHASAN}

Keterampilan proses sains siswa kelas XI.MIPA.1 SMA Negeri 3 Muaro Jambi Tahun Pelajaran 2017/2018 pada materi pokok dunia tumbuhan (plantae) dengan menggunakan model pembelajaran berbasis lingkungan dapat dilihat dari peningkatan sebagai berikut:

keterampilan mengoservasi dengan indikator: 1) mengamati objek yang ditemukan meningkat dari $74,4 \%$ menjadi $80 \%$. 2) mengumpulkan fakta dan data sesuai hasil pengamatan meningkat dari $72 \%$ menjadi $78 \%$, keterampilan mengklasifikasi dengan indicator. 
1) mencari ciri-ciri pada masing-masing objek meningkat dari 70,3\% menjadi $78 \%, 2$ ) mencari persamaan dan perbedaan masing-masing objek meningkat dari $70 \%$ menjadi $77 \%$, 3) membandingkan objek berdasarkan ciri-cirinya meningkat dari $69 \%$ meningkat menjadi $74 \%$, kerja sama kelompok dengan indikator a) ikut mengamati objek yang ditemukan meningkat dari $74 \%$ menjadi $77,2 \%$, b) ikut mencari objek dilingkungan meningkat dari $73 \%$ menjadi $77,3 \%$, c) mengajukan pendapat dalam kelompok meningkat dari $65 \%$ menjadi $76 \%$, d) menanggapi pendapat dari teman kelompok meningkat dari $64,5 \%$ menjadi $75 \%$.

Keterampilan mengkomunikasikan dengan indikator a) menjelaskan hasil pengamatan secara lisan meningkat dari $74 \%$ menjadi $79,3 \%$, b) menyampaikan perolehan dalam bentuk tabel meningkat dari 73,9\% menjadi $79 \%$, c) mengajukan pertanyaan dengan kelompok yang presentasi meningkat dari $63 \%$ menjadi $78,2 \%$, d) menjawab pertanyaan darianggota kelompok lain meningkat dari $70 \%$ menjadi $78 \%$.

Sedangkan hasil belajar kognitif siswa mengalami peningkatan dari prasiklus ke siklus II. Pada prasiklus yaitu 60,6\% meningkat menjadi 65,3\% pada siklus I, dan dari siklus I yaitu $65,3 \%$ meningkat menjadi $77,2 \%$ pada siklus. Berdasarkan hasil pengamatan keterampilan proses sains tersebut, maka dapat dilihat pengembangan keterampilan proses sains siswa dalam tabel berikut:

Tabel 2. Data Peningkatan Keterampilan Proses Sains antara Siklus I dengan Siklus II

\begin{tabular}{|c|c|c|c|c|c|}
\hline No & Aspek yang dinilai & $\begin{array}{l}\text { Target yang } \\
\text { Ingin dicapai }\end{array}$ & SilkusI & $\begin{array}{l}\text { Siklus } \\
\text { II }\end{array}$ & Peningkatan \\
\hline 1 & $\begin{array}{l}\text { Keterampilan mengobservasi } \\
\text { a. Mengamati objek yang ditemukan di } \\
\text { lingkungan } \\
\text { b. Mengumpulkan fakta yang relevan dan } \\
\text { memadai sesuai dengan hasil } \\
\text { pengamatan }\end{array}$ & $\begin{array}{l}\geq 80 \% \\
\geq 80 \%\end{array}$ & $\begin{array}{c}74,4 \% \\
72 \%\end{array}$ & $\begin{array}{l}80 \% \\
78 \%\end{array}$ & $\begin{array}{l}+5,6 \% \\
+6 \%\end{array}$ \\
\hline 2 & $\begin{array}{l}\text { Keterampilan mengklasifikasikan objek } \\
\text { a. Mencari ciri-ciri pada masing-masing } \\
\text { objek pengamatan } \\
\text { b. Mencari persamaan dan perbedaan } \\
\text { pada objek pengamatan berdasarkan } \\
\text { ciri-cirinya } \\
\text { c. Membandingkan objek pengamatan } \\
\text { berdasarkan ciri-cirinya }\end{array}$ & $\begin{array}{l}\geq 75 \% \\
\geq 75 \%\end{array}$ & $\begin{array}{l}70 \% \\
69 \%\end{array}$ & $\begin{array}{l}77 \% \\
74 \%\end{array}$ & $\begin{array}{l}+7 \% \\
+5 \%\end{array}$ \\
\hline 3 & $\begin{array}{l}\text { Keterampilan sosial/kerjasama kelompok } \\
\text { a. Ikut mengamati masing-masing } \\
\text { objek/tumbuhan yang ditemukan } \\
\text { b. Ikut mencari objek/tumbuhan } \\
\text { dilingkungan } \\
\text { c. Mengajukan pendapat dalam } \\
\text { kelompoknya } \\
\text { d. Menanggapi pendapat dari teman } \\
\text { kelompok }\end{array}$ & $\begin{array}{l}\geq 75 \% \\
\geq 75 \% \\
\geq 75 \% \\
\geq 75 \%\end{array}$ & $\begin{array}{l}74 \% \\
73 \% \\
65 \% \\
64,5 \%\end{array}$ & $\begin{array}{l}77,2 \% \\
77,3 \% \\
76 \% \\
75 \%\end{array}$ & $\begin{array}{l}+3,2 \% \\
+4,3 \% \\
+9 \% \\
+10,5 \%\end{array}$ \\
\hline 4 & $\begin{array}{l}\text { Keterampilan mengkomunikasikan } \\
\text { a. Menjelaskan hasil pengamatan secara } \\
\text { lisan } \\
\text { b. Menyampaikan perolehan dalam tabel } \\
\text { c. Mengajukan pertanyaan dengan } \\
\text { kelompok yang presentasi } \\
\text { d. Menjawab pertannyaan dari anggota } \\
\text { kelompok lain }\end{array}$ & $\begin{array}{l}\geq 75 \% \\
\geq 75 \% \\
\geq 75 \% \\
\geq 75 \%\end{array}$ & $\begin{array}{c}74 \% \\
73,9 \%\end{array}$ & $\begin{array}{c}79,3 \% \\
79 \%\end{array}$ & $\begin{array}{l}+5,3 \\
+5,1 \% \\
+15,2 \\
+8 \%\end{array}$ \\
\hline
\end{tabular}




\section{SCIENCE : Jurnal Inovasi Pendidikan Matematika dan IPA Vol. 1 No. 2 Agustus 2021 e-ISSN : 2797-1031 | p-ISSN : 2797-0744}

Berdasarkan hasil analisis data di atas dapat dikatakan bahwa model pembelajaran berbasis sumber belajar lingkungan dapat mengembangkan keterampilan proses sains siswa. Begitu juga dapat meningkatkan hasil belajar siswa kelas XI.MIPA.I SMA Negeri 3 Muaro Jambi pada materi tumbuhan (Plantae).

Berdasarkan penjelasan di atas dapat disimpulkan lingkungan dapat digunakan untuk mengembangkan keterampilan proses sains siswa. Keterampilan proses yang dikembangkan dalam penelitian ini yaitu keterampilan mengobservasi dengan indikator siswa mampu mengamati objek langsung yang ditemukan di lingkungan sekitar dengan menggunakan beberapa indra seperti penglihatan, penciuman dan perabaan. Setelah melakukan pengamatan siswa mengumpulkan dan memproses data yang sesuai dan relevan dengan hasil pengamatan. Data yang diperoleh dituangkan dalam Lembar Kerja Siswa (LKS). Keterampilan selanjutnya adalah keterampilan mengklasifikasikan objek. Keterampilan mengklasifikasikan objek yang dimaksud dalam penelitian ini adalah keterampilan siswa mengelompokkan objek biologi dalam golongan tertentu.

Dalam hal ini yaitu ketika siswa mampu mengelompokkan dunia tumbuhan kedalam golongan tertentu. Dengan demikian yang menjadi indikator dari keterampilan ini adalah siswa mampu mencari ciri-ciri pada masing-masing objek pengamatan, setelah itu siswa mencari persamaan dan perbedaan pada masing-masing objek dan membandingkan objek berdasarkan ciri-cirinya. Dengan model pembelajaran berbasis sumber belajar lingkungan ini siswa juga diharapkan memiliki keterampilan dalam sosialnya. Karena pada pembelajaran ini dilakukan di lingkungan siswa mencari objek pengamatan di lingkungan secara berkelompok sehingga siswa diharapkan dapat bekerja sama dengan kelompoknya. Indikator dari keterampilan sosial/kerjasama dalam kelompok adalah siswa ikut terlibat dalam mengamati objek yang ditemukan di lingkungan, siswa ikut terlibat dalam mencari objek di lingkungan, siswa mampu mengajukan pendapat dalam kelompoknya, dan menanggapi pendapat dari teman kelompok. Setelah mengamati, mengklasifikasi, dan kerja sama dalam kelompok, keterampilan yang lain yang dikembangkan yaitu keterampilan mengkomunikasikan. Keterampilan mengkomunikasikan yang dimaksud adalah keterampilan siswa dalam menyampaikan perolehan secara sistematis dari data hasil pengindraan atau hasil pengamatan, dan dapat mengutarakan suatu gagasan. Keterampilan menyampaikan perolehan ditunjukan ketika siswa melakukan kegiatan presentasi didepan kelas dalam bentuk lisan, tulisan, gerak atau gambar. Hal ini sesuai pendapat Dimyati dan Mudjiono (2002: 30) bahwa "Keterampilan menyampaikan sesuatu secara lisan maupun tulisan termasuk komunikasi. Mengkomunikasikan dapat diartikan sebagai penyampaikan dan memperoleh fakta, konsep, dan prinsip ilmu pengetahuan dalam bentuk suara, visual, atau suara dan visual. Dari penjelasan ini yang menjadi indikator dari keterampilan mengkomunikasikan adalah siswa mampu menjelaskan hasil pengamatan secara lisan, siswa mampu menyampaikan perolehan dalam bentuk tabel, siswa mampu mengajukan pertanyaan dengan kelompok presentasi, dan mampu menjawab pertanyaan dari anggota kelompok lain.

Hasil penelitian ini juga sejalan dengan beberapa teori yang dikemukakan. Berdasarkan hasil penelitian Siregar(2017) menyatakan "Secara teknis pelaksanaan pembelajaran berbasis lingkungan dengan media pembelajaran lingkungan sekitar sekolah dapat menggunakan ramuan atau campuran berbagai macam metode pembelajaran. Seperti metode Contextual Teaching and Learning (CTL), demonstrasi, inquiri, eksperimen hingga metode pembelajaran terkini yang beragam jenisnya. Metode-metode tersebut dapat dipilih satu persatu atau dicampur/diramu disesuaikan dengan indikator apa yang ingin dicapai setelah pembelajaran selesai". Pada penelitian guru menggunakan metode CTL karena salah satu prinsip dari metode ini menurut Komalasari (2010:14) yaitu adanya pengalaman langsung (experiencing) yaitu proses pembelajaran yang memberikan kesempatan pada siswa untuk mengkontruksi pengetahuan dengan cara menemukan dan mengalami sendiri secara langsung, dalam aplikasinya model pembelajaran berbasis lingkungan ini siswa mengalami langsung dengan mengamati objek langsung yaitu tumbuh-tumbuhan yang ditemukan di lingkungan kemudian 


\section{SCIENCE : Jurnal Inovasi Pendidikan Matematika dan IPA Vol. 1 No. 2 Agustus 2021 e-ISSN : 2797-1031 | p-ISSN : 2797-0744}

menemukan pengetahuan sendiri dari pengamatan tersebut. Pembelajaran secara langsung dengan objek dapat meningkatkan ingatan yang lebih mendalam kepada siswa dan konsepkonsep abstrak akan lebih mudah dipahami oleh siswa jika siswa mengalaminya secara langsung. Selain CTL dalam model pembelajaran berbasis lingkungan guru juga menerapkan metode inquiri dengan metode ini siswa diharapkan menemukan sendiri jawaban atas permasalahan yang ingin dipecahkan melalui observasi (observation) terhadap objek, bertanya (questioning), mengajukan dugaan (hipotesis), pengumpulan data (data collecting) dan penyimpulan (conclussion) dari kegiatan-kegiatan tersebut siswa akan lebih mudah memahami konsep dunia tumbuhan (plantae) dan akan berpengaruh dengan hasil belajar siswa.

Model pembelajaran berbasis lingkungan dengan menggunakan lingkungan sebagai sumber belajar, memiliki manfaat yang sangat besar yakni memberikan motivasi belajar, mengarahkan aktivitas belajar siswa, memperkaya pengetahuan dan informasi, meningkatkan hubungan sosial, memperkenalkan lingkungan, menumbuhkan sikap apresiasi terhadap lingkungan sekitarnya. Hasil belajar yang diharapkan dengan model tersebut adalah dalam rangka pencapaian tujuan perolehan hasil belajar siswa dalam implementasinya meningkatkan kompetensi kognitif, kompetensi keterampilan sosial, keterampilan proses sains dan kecintaan terhadap lingkungan. Menurut Komalasari (2010:139) bahwa "Lingkungan tempat tinggal dan sekolah merupakan bagian tak terpisahkan dari aktivitas keseharian siswa. Oleh sebab itu, lingkungan dapat dimanfaatkan sebagai sarana untuk mengembangkan kemampuan-kemampuan siswa dalam proses pembelajaran seperti mengamati, mengklasifikasikan, menggolongkan, menurunkan, meramaikan, memprediksi, mengukur, menafsirkan, mengkomunikasikan, membuat definisi, merumuskan pertanyaanpertanyaan dan hipotesis, melakukan eksperimen dan sebagainya. Dengan metode-metode ini siswa diajak untuk berpikir secara alamiah, bebas menghargai pendapat orang lain, dan bekerja sama dengan temannya. Dengan demikian, siswa akan belajar memecahkan persoalanpersoalan tentang lingkungan kemasyarakatan serta lingkungan fisiknya.

\section{KESIMPULAN}

Berdasarkan hasil penelitian yang dilakukan, dapat disimpulkan bahwa: 1) Penerapan model pembelajaran berbasis sumber belajar lingkungan dapat mengembangkan keterampilan proses sains siswa kelas XI.MIPA.1 SMA Negeri 3 Muaro Jambi semester genap tahun ajaran 2017/2018, pada materi pokok dunia tumbuhan (plantae). 2) Penerapan model pembelajaran berbasis lingkungan dapat meningkatkan hasil belajar kogntif pada siswa kelas XI.MIPA.1 SMA Negeri 3 Muaro Jambi semester genap tahun ajaran 2017/2018 pada materi pokok dunia tumbuhan (plantae).

\section{DAFTAR PUSTAKA}

Asih, D. A. S. (2017). Pengaruh penggunaan fasilitas belajar di lingkungan alam sekitar terhadap keterampilan proses sains. Formatif: Jurnal Ilmiah Pendidikan MIPA, 7(1).

Daryanto,(2014). Pembelajaran Tematik, Terpadu, Terintegrasi (Kurikulum 2013). Jogjakarta: Gava Media.

Dimyati,\&Mujiono. (2002). Belajar dan Pembelajaran. Jakarta: Direktorat Jendral Pendidikan Tinggi

Hasbullah. (2012). Dasar-Dasar Ilmu Pendidikan.Jakarta: PT. Raja Grafindo Persada.

Khojin, Nur., Utami, Syaifulloh, 2017. Pengaruh Tingkat Pendidiikan Terhadap Produktivitas Kerja Pembutik Bawang di Sub Terminal Agribisnis Larangan. Syntax Idea Vol 2, No. 5 Mei 2017.

Komalasari, Kokom. (2010).Pembelajaran Kontekstual Konsep dan Aplikasinya. Bandung: Refika Aditama.

Midin, D. F. S. (2013). pengaruh lingkungan sekitar sekolah sebagai sumber belajar melalui model inkuiri terbimbing terhadap keterampilan proses sains dan penguasaan konsep 
pada materi pokok ekosistem (Studi Eksperimen pada Siswa Kelas VII Semester Genap SMP N 4 Sekampung Kabupaten Lampung Timur Tahun Pelajaran 2012/2013).

Muhammad Muslich, 2016. Pengaruh Lingkungan Keluarga dan Lingkungan Sekolah terhadap Prestasi Belajar Siswa Kelas 6 SDN Limbangan. Syntax Literate. Vol. 1, No. 4.

Mudjiono dan Dimyati. (2006). Belajar dan Pembelajaran. Jakarta: Rineka Cipta.

Pertiwi, N., Yolida, B., \& Sikumbang, D. (2017). Hubungan Pelaksanaan Praktikum dengan Hasil Belajar dan Keterampilan Proses Sains. Jurnal Bioterdidik: Wahana Ekspresi Ilmiah, 8(1), 27-35.

Rahmatiah. 2015. Pendekatan Sainstifik sebagai solusi dalam pembelajaran Biologi. Sulawesi Selatan: Artikel E-Buletin Media Pendidikan LPMP Sulsel Edisi Mei 2015 ISSN. 2355-3189.

Sariningsih, R., \& Kadarisma, G. (2016). Meningkatkan Kemampuan Berpikir Kreatif Matematis dan Kemandirian Belajar Siswa SMP Melalui Pendekatan Saintifik berbasis Etnomatematika. Jurnal Ilmiah P2M STKIP Siliwangi, 3(1), 53-56.

Siregar, P. S., Wardani, L., \& Hatika, R. G. (2017). Penerapan Pendekatan Pembelajaran Aktif Inovatif Kreatif Efektif Dan Menyenangkan (Paikem) Pada Pembelajaran Matematika Kelas Iv Sd Negeri 010 Rambah. Jurnal Pemikiran dan Pengembangan Sekolah Dasar (JP2SD), 5(2), 743-749.

Tussaadiyah, H. (2017). Penerapan Model Pembelajaran Creative Problem Solving Untuk Meningkatkan Hasil Belajar. Syntax Literate; Jurnal Ilmiah Indonesia, 2(11), 50-62.

Wahid, F. S., Setiyoko, D. T., Riono, S. B., \& Saputra, A. A. (2017). Pengaruh Lingkungan Keluarga Dan Lingkungan Sekolah Terhadap Prestasi Belajar Siswa. Syntax Literate; Jurnal Ilmiah Indonesia, 5(8), 555-564.

Wahyuni, S. (2017). Implementasi pendekatan sainstifik pada pelajaran biologi untuk meningkatkan hasil belajar kognitif dan keterampilan sains siswa kelas xi-Biologi sma negeri 2 lambandia, kab. kolaka timur-sultra. Jurnal Pendidikan Biologi, 9(2), 47-55. 